\title{
Construction and Demolition Waste Management Scenario in Republic of Cape Verde-The Case Study of City of Praia
}

\author{
Luciene Eveline Semedo Vaz, Leandro Vahia Pontual, \\ Fernando Benedicto Mainier, Ana Lúcia Torres Seroa da Motta \\ Department Pós-Graduação em Engenharia Civil, Universidade Federal Fluminense, Niterói, Brazil \\ Email: lucienesemedovaz@gmail.com
}

How to cite this paper: Vaz, L.E.S., Pontual, L.V., Mainier, F.B. and da Motta, A.L.T.S. (2016) Construction and Demolition Waste Management Scenario in Republic of Cape Verde-The Case Study of City of Praia. Journal of Environmental Protection, 7, 2009-2017.

http://dx.doi.org/10.4236/jep.2016.713155

Received: October 6, 2016

Accepted: December 11, 2016

Published: December 14, 2016

Copyright $\odot 2016$ by authors and Scientific Research Publishing Inc. This work is licensed under the Creative Commons Attribution International License (CC BY 4.0).

http://creativecommons.org/licenses/by/4.0/

\section{Abstract}

Globally, the construction industry is one of the leading producers of solid waste. The city of Praia, the capital of the Republic of Cape Verde has been suffering from environmental degradation with the irregular disposal of waste caused by inadequate management of waste from construction and also the demolition. The research was developed based on local inspections in the context of environmental laws, in semistructured interviews with people who deal with this activity and bibliographic references. The main conclusion is that the city does not have a CDW management plan consequently leading to environmental problems. On the other hand, waste of recycled construction can be used as inert reducing the consumption of raw materials that can be used as base and sub-base for paving, landfills, aggregate in mortars and raw materials to be manufactured blocks, bricks concrete tiles, etc.

\section{Keywords}

Construction Management, Construction and Demolition Waste, Sustainability, Environmental Impact

\section{Introduction}

As a result of growing environmental vision in the world, both governments and the construction industry companies have considered efficient, sustainable practices for management of construction and demolition waste (CDW) [1]. The construction sector in the world accounts between $10 \%$ and $30 \%$ of all construction waste, thus several countries have developed over the year's regulations and guidelines to manage and encourage recycling [2]. The construction industry is the largest consumer of natural re- 
sources like water, aggregates, soil, fossil fuels, but also one of the largest producers of greenhouse gases like carbon dioxide $\left(\mathrm{CO}_{2}\right)$ produced in cement factories and hydrocarbons generated in the asphalt confection and finally, largely responsible for the production of solid waste [3]. Each year the generation of waste is extended, exceeding the already daunting levels. Many authors points out that the global production of waste is outpacing population growth and the difficult situation of waste management is drastic emerging cities [4] [5]. [6] reports the mismanagement and the large production of waste at the construction site. For these problems a good organization, proper waste storage, efficient screening and custom recycling help minimize the issue.

The increasing of construction waste amount reaches African countries, as in the case of Cape Verde and especially the city of Praia. The large amount of solid waste is illegally thrown at the environment, and the lack of specific areas of disposal, inadequate recycling and management system weaknesses are some flaws that allow environmental degradation [7].

Although the legislation exists, there is a failure in its implementation. The recycling of CDW is not a part of the reality in Cape Verde. Considering these problems, the objective of this manuscript is to study technical and general aspect of construction and demolition waste management in Cape Verde Republican specifically in Praia, analyzing important factors to better understand the problem and search for solution. This report is expected to be a pilot study towards developing at a CDW manual in Cape Verde.

\subsection{Characterization of the Study Area County of Praia in Cape Verde}

Cape Verde is a small archipelago of tenislands: Santo Antao, Sao Vicente, Santa Luzia, Sao Nicolau, Sal, Boa Vista, Maio, Santiago, Fogo and Brava (Figure 1). All of volcanic origin on the West Coast of Africa, between the parallel $14^{\circ} 48^{\prime} \mathrm{N}$ and $17^{\circ} 12^{\prime} \mathrm{N}$, and the meridians $22^{\circ} 44^{\prime} \mathrm{W}$ and $25^{\circ} 22^{\prime} \mathrm{W}$, from arid to semi-arid climate, and Portuguese as official language. It has an area of 4033 square kilometres, and the insular nature concentrated in Santiago island is of $991 \mathrm{~km}^{2}$ corresponding to $24.6 \%$ of its national territory. The country has a fragile ecosystem as result of low volume of rainfall [8]. The city of Praia in Santiago Island is the capital of the Republic of Cape Verde, with an area of 258 square kilometers and population of 151,436 inhabitants according to the statistical yearbook of the National Institute of Statistics INE (2015).

In Pin Praia, according to the National Agency of Water and Sanitation [9] not having a specific plan of CDW management and the irregular deposition of CDW on the outskirts and suburbs is one of the environmental problems.

Construction in Cape Verde started the use of new technologies. However, sustainable practices in the building do not follow this adjustment. Factors such as the economic cultural and architectural typologies, hinder the advance [10].

In agreement [11], says that the absence of coherent actions at the construction site in Cape Verde causes waste and losses of natural resources as water, sand, gravel, etc. 


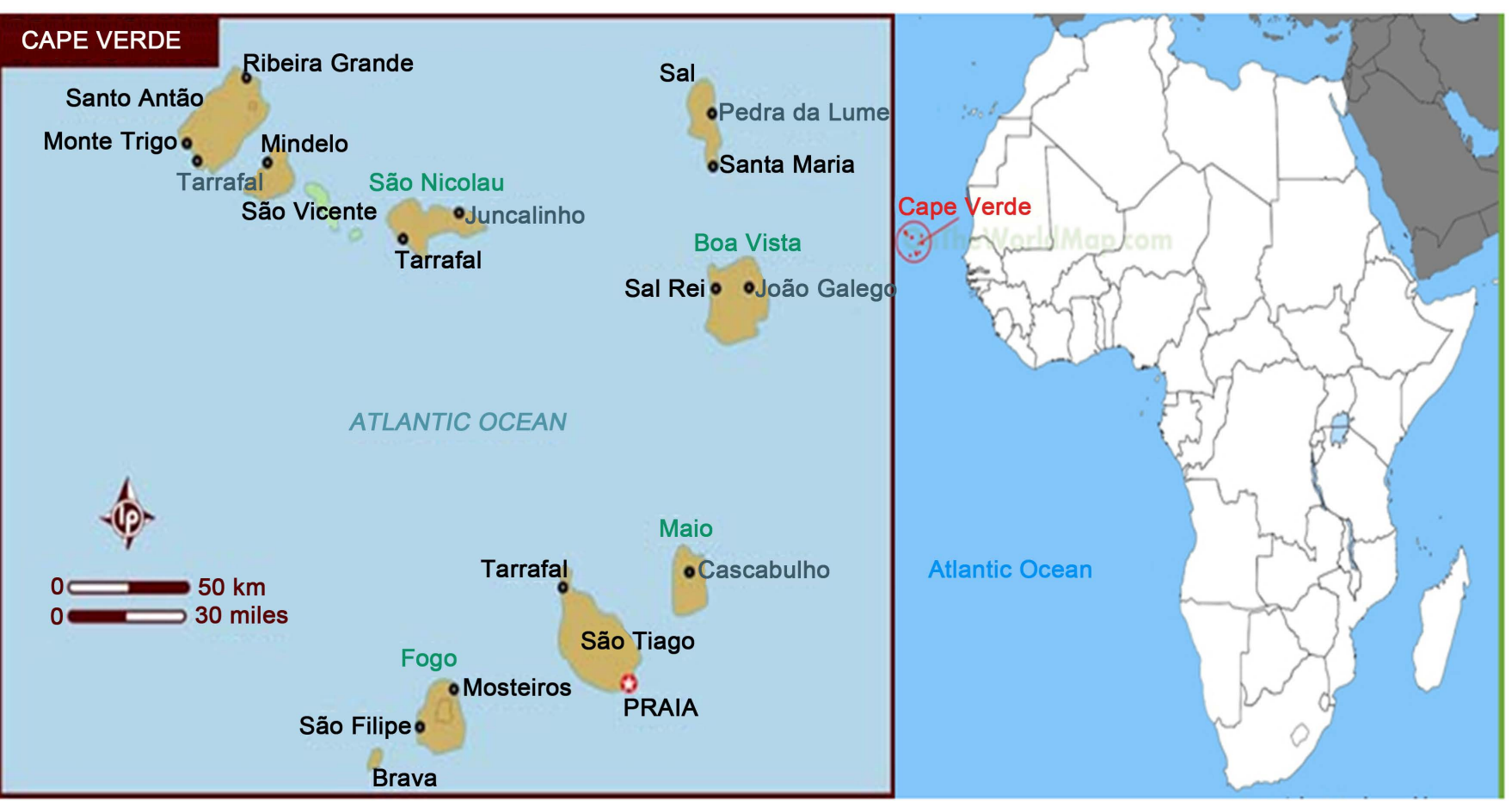

Figure 1. Cape verd maps.

generating volumes of CDW. However, it considers that the deficiency in raising public awareness, unskilled workers, sustainable standards that support good management in construction and the gap in the recycling systems are among the possible causes. According to the same author, a systemic culture of raw materials preservation is not employed, resulting from disqualified labour, plus there is a direct correlation with the technology used. The losses and waste on the construction site in Cape Verde have been between $10 \%$ and $60 \%$ depending on the type of work.

In a case study in a residential project in Praia [12], it shows that there is a deficiency in training and qualification of skilled labor, according to the chart, only $15 \%$ of all workers had technical training for the position held (Figure 2). Depending on the data collected is suggested the need to implement technical training programs to minimize the technical knowledge deficit of workers.

\subsection{Legal Framework in Cape Verde}

Since the year of 1993 decree laws, relating to environmental protection and waste generation, are published in the official government bulletin, as the decree-law 86/IV/ 93 of June 26th which brings the definition of environmental policy bases and decree-law $31 / 2003$ of September 1st that establishes the requirements to be considered in waste disposal for environmental protection and public health, and national plan for solid waste PANA I, alternative methods to contain and limit the use of sand in construction and public works PANA II. However, these resolutions had no specific waste management guidelines waste management of construction and demolition. 


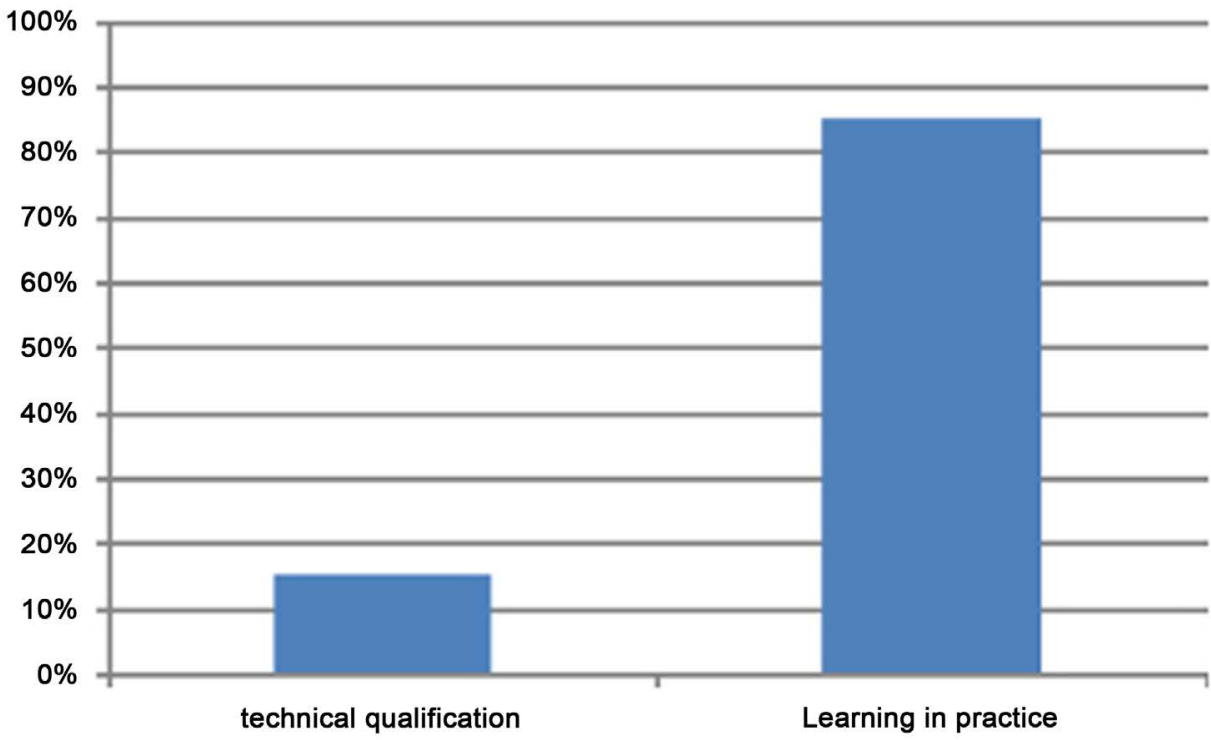

Figure 2. Qualification of construction works in Praia.

In October 2015, it entered in to force also government decree 56/2015 that regulate the management of waste from the construction and demolition (C\&D), and strategic plan for waste management and prevention PENGER prepared by the National Agency of Water and Sanitation [9]. According to decree-law 56/2015 of waste management, published in B.O. \# 62 series I, of the Republic of Cape Verde, which revoked decreelaw 31/2003 of September 1st and decree-law 12/2012 of April 17th. Defines waste construction and demolition as:

"The residue from construction, reconstruction, extension, alteration, maintenance and demolition of buildings and collapse".

Decree Law 56/2015 was drafted with the aim of:

"Establish key concepts such as waste definitions, prevention, reuse, preparation for reuse, treatment and recycling, and the distinction between the concepts of recovery and disposal of waste, based on a real difference in terms of environmental impact, Designates It was further to a system of prevention and waste management, use of construction and demolition waste in the work of sorting and fragmentation of waste from construction and demolition, construction waste management and demolition work, prevention and management plan waste from construction and demolition."

The characterization of construction waste in Cape Verde is included within the waste category. The classification of waste produced in Cape Verde, according to the PANA II is made considering the origin of the waste: municipal solid waste (MSW); Large waste; Industrial waste; Hazardous waste; Construction and demolition waste; sludge and septic tanks; Hospital waste; Slaughterhouse waste; Waste wild dumps; Tires; Batteries and accumulators.

Figure 3 shows the gravimetric study of the composition of the waste, according to the National Agency of Water and Sanitation [9]. The percentage of total CDW in Cape Verde is equivalent to $3.8 \%$ of all total waste. However, it doesn't consider cat egories 


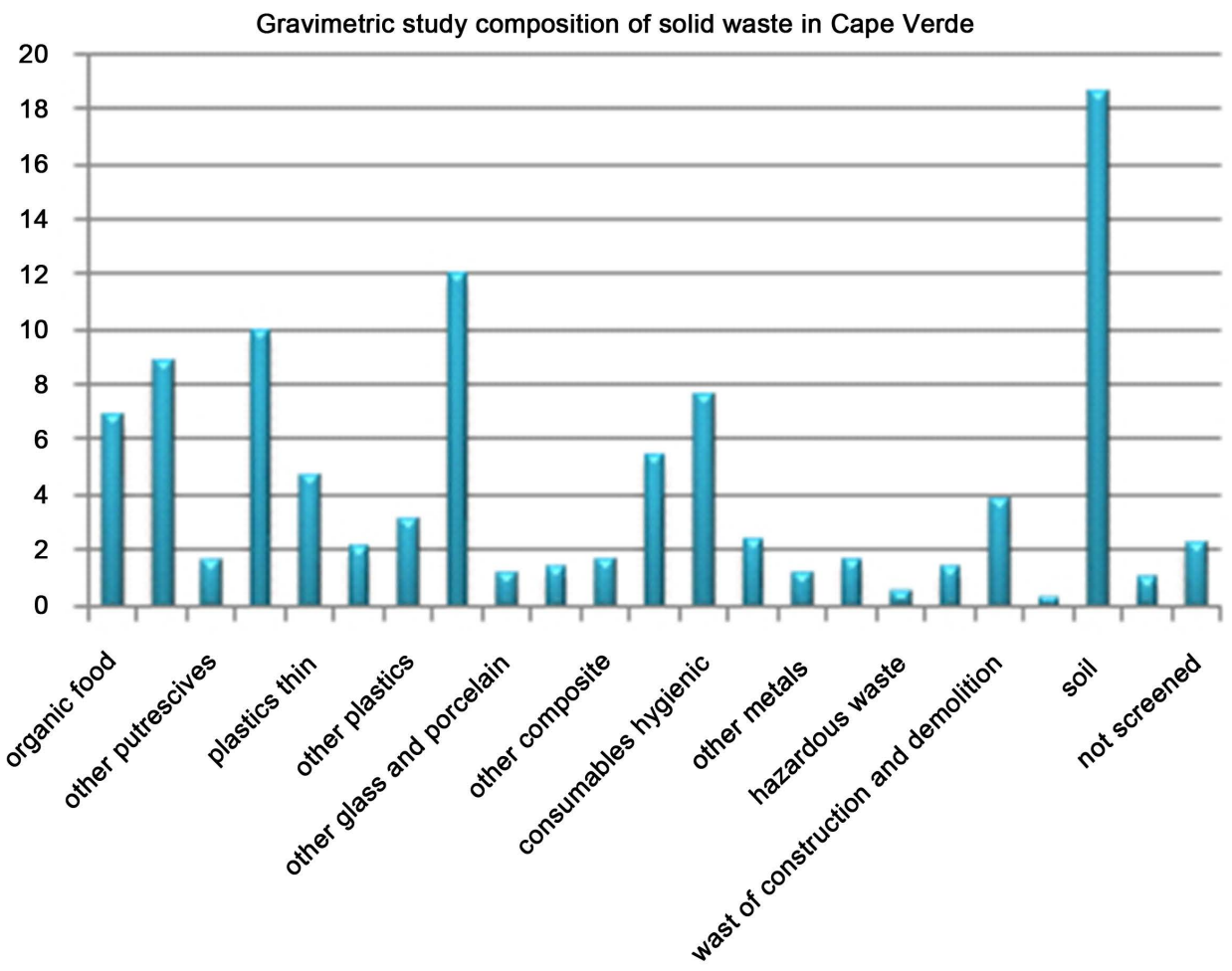

Figure 3. Gravimetric study composition of solid waste in Cape Verde.

as soils, woods, ceramics, electrical wiring and windows, some metal items that are part of activities related to civil construction according to decree-law 56/2015. The Given items percentage of CDW would be $27.9 \%$, then there is a disagreement between the strategic plan and decree-law 56/2015 that places the plan as material support, this discrepancy undermines the efficiency of the Waste Management Construction.

\section{Materials and Methods}

This research was structured using as method the study of construction management waste in the county of Praia in the republic of Cape Verde. The collected data are from the end of 2015 and beginning of 2016 in Praia, through visits to strategic points used for disposal of construction and demolition waste. The interview was conducted in the month of August 2016. For having scarce data on CDW in Praia, much of this research was carried out on site by means of literature review books, articles, dissertations, these and the relevant legislation to the subject, and through interview with the City Hall of Praia. To register and catalog visits in Praia was used a camera and a notepad with relevant circumstantial notes.

\section{Results}

\subsection{Interview: Construction and Demolition Waste Management in Praia City}

According to data collected through interviews by e-mail, the person responsible for 
waste management from Praia's city hall (CHP) says the city contracts a outsourced service to collect the municipal solid waste (MSW), but still hasn't a CDW. The MSW collection system is made by hermetic and opened box trucks. To assist, there are containers of 1100 and 800 liters and 8 and $4 \mathrm{~m}^{3}$ distributed throughout the city, the CDW must be transported to the landfill by producers under penalty fine.

According to CHP, 2016 has been discussing a municipal regulation project for waste, health and public hygiene. Also in analysis and discussion are proposals for a treatment plant or recycling. A landfill bigger than the current one with more capacity is already built in the Council of Sao Domingos and was scheduled for April this year, but is not yet in use. According to the city council of Praia the current space designated to waste deposition is located far from urban areas. This distance minimizes the contamination of the population, despite frequented by people seeking for a subsidy in the trash. However, the integrated system is still treated as a future project. It is found a lack of conditions to meet the paragraph 1st and 2nd of article 51 of decree-Law 56/ 2015 of the Republic of Cape Verde which says:

"1st paragraph: The materials that are impossible to reuse and compose construction waste and demolition are necessarily subject to screening in work aiming to be sent, by streams and rows of materials for recycling or other recovery or disposal."

"2nd paragraph: In situations where it cannot be done the sorting of construction and demolition waste in the work, or in a place intended for it, the respective producer is responsible for its referral to licensed management operator or concession for this purpose."

\subsection{Environmental Impact of Illegal Discard in Praia City}

Inappropriate waste disposal from construction and demolition degrade the environmental quality on the planet. Although, the construction industry [13], can attenuate this environmental impact through the use of more ecologically correct construction technologies, replacing natural materials in shortage for recycled materials or even for those generated during construction activity. Sustainable construction is a very important aspect to mitigate the environmental impact related to the industry and when associated with factors such as changes in product programs, use of softer environmental impact materials, reuse of materials, proper training for workers, especially, making them aware of the process they part of, it allows a better tracing of the work activities course. That ideal scenario of a sustainable technological development can leverage the performance of a company and present a breakthrough for the construction industry. For less sustainable strategies applied, more waste will be produced.

On-site visited Debris thrown at the outskirts of Praia near to the urban center, urban road, sidewalks, schools, and even close to groundwater withdrawal wells, CDW without any screening as shown in Figure 4 and Figure 5 disrespecting the decree-law $86 /$ IV/93 of June 26th and decree-law 56/2015. These waste, according to data from [9], harm the population, deteriorates the environment, contaminating wells, causing floods, visual pollution, and also causing the proliferation of diseases such as malaria and cholera, typical from African regions. 


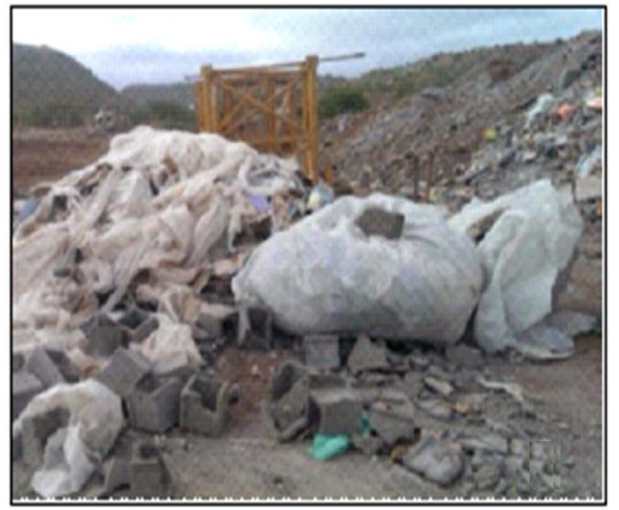

(a)

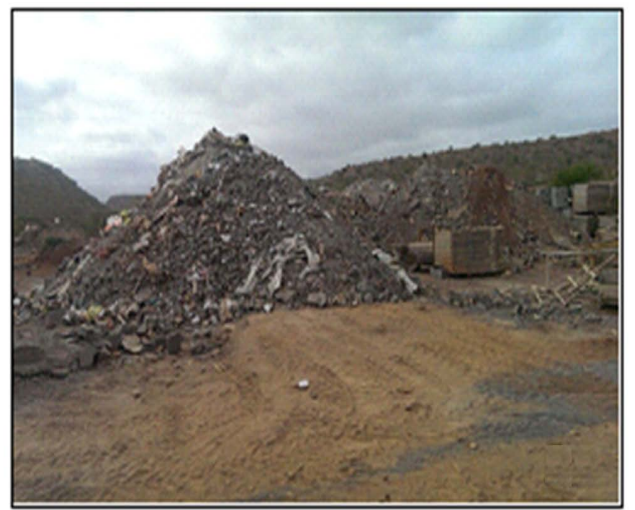

(b)

Figure 4. (a) Irregular dispose in Achada Grande Frente rapid transit airport route Nelson Mandela $3 \mathrm{~km}$ from the center of Praia; (b) Irregular dispose in Palmarejo Grande $6.1 \mathrm{~km}$ from the center of Praia.

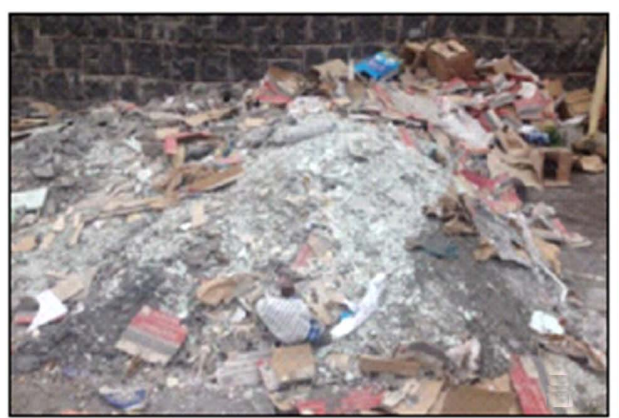

(a)

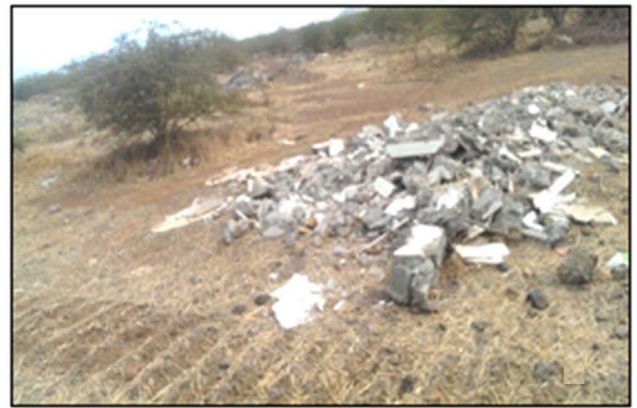

(b)

Figure 5. (a) Irregular dispose in pavement in Fazenda neighborhood to Center of Praia; (b) Irregular dispose in Achada São Filipe $3.4 \mathrm{~km}$ from the center of Praia.

In Figure 6, the findings relating to irregular seating arrangements of construction waste in Praia are displayed.

As we can see in Figure 4 and Figure 5, the diversified composition of debris, highlights the need of a collection and sorting system for small volumes. Another item seen in Figure 6 is the variety of irregular disposal areas, different spots are used as disposal areas: $53 \%$ in wastelands, $21 \%$ on urban roads, $19 \%$ in common areas and side roads and $7 \%$ in the construction site. Both collected data point to the importance of public consciousness for caring for the environment, and the need to invest in the recycling of CDW to reduce these numbers.

Reference [14] points out that the future of the management of construction and demolition waste depends on the reuse and recycling of materials, because maintaining efficient environmentally friendly landfills are overly expensive.

In agreement [15] recycling and reuse are important tools to reduce the amount of waste dumped in landfills, and selective demolition and deconstruction policies facilitate the implement of these tools. 


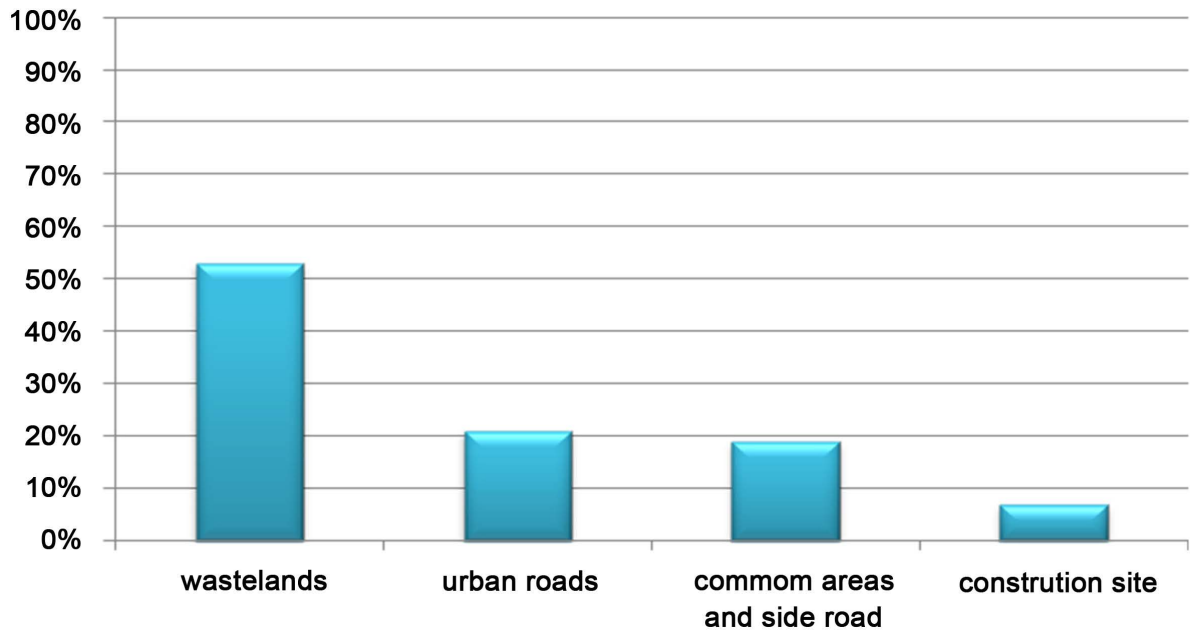

Figure 6. Place used for irregular disposal CDW $\times$ percentage by place.

\section{Conclusions}

The construction and demolition waste management is very important to achieve environmental sustainability in its all aspects, for example, bringing positive social impact with opportunities and improvements of resources and work quality, preventing landscapes to get contaminated and reducing environmental degradation. Both economic and environmental interests are benefited, when optimizing the management and practical collection, treatment and recycling of waste.

Governments and municipalities have a crucial role to facilitate and employ sustainable measures. According to the collected data, the population is unaware of the environmental protection rules and has little respect for it, and several areas have been marked as irregular waste disposal. Therefore, it is necessary not only to create regulations and guidelines, but create ways to the population to absorb it.

The legislation regarding the construction waste is unclear, allowing multiple interpretation, because its characterization doesn't specify and classify with efficiency what is titled as waste. The 2016 national waste management plan is an advance and important instrument to help the legislation, but still has a precarious gravimetric interpretation of the CDW composition that doesn't include obvious items of construction and demolition waste, leaving yet a challenge for the country. A specific plan for construction and demolition is needed. For instance, the SIG tool (management information systems), used to assist in the monitoring and management of waste in cities, to be incorporated as a preventive and corrective measure technique. The responsible bodies should put into practical methods such as: encourage the use of recycled construction waste as aggregates in mortars, reducing the consumption of raw materials in public operations; encouraging the use of CDW as a base and sub-base paving, sidewalks, embankments, manufactured blocks, concrete bricks, tiles; promoting an effective change in economic, social and political relationship between society and trash responsibility. 


\section{References}

[1] Cheng, J.C.P. and Ma, L.Y.H. (2013) A BIM-Based System for Demolition and Renovation Waste Estimation and Planning. Waste Management, 33, 1539-1551.

[2] Merino, M.R., Gracia, P.I. and Azevedo, I.S.W. (2010) Sustainable Construction: Construction and Demolition Waste Reconsidered. Waste Management \& Research, 28, 118-129. https://doi.org/10.1177/0734242X09103841

[3] Srour, I., Chehab, G. and Gharib, N. (2012) Recycling Construction Materials in a Developing Country: Four Case Studies. International Journal of Engineering Management and Economics, 3, 135-151. https://doi.org/10.1504/ijeme.2012.048609

[4] Waldman, M. (2010) Lixo: cenários e desafios. Cortez, São Paulo.

[5] Kennedy, C., Hoornweg, D. and Bhada-Tata, P. (2013) Waste Production Must Peak This Century. Macmillan Publishers Limited, C-Nature, 615-617.

[6] Pinto, T.M. (1995) Metodologia para a gestão diferenciada de resíduos sólidos da construção urbana. (Tese) Escola Politécnica da Universidade de São Paulo 1995. http://www.casoi.com.br/hjr/pdfs/GestResiduosSolidos.pdf

[7] Jacobi, P.R. and Besen, G.R. (2011) Gestão de resíduos sólidos em São Paulo: desafios da sustentabilidade. Estudos Avançados, 25, 137-158. https://doi.org/10.1590/s0103-40142011000100010

[8] INE (2015) Anuário estatístico de Cabo Verde. http://www.ine.cv/anuarios/Anuario_CV_2015.pdf

[9] ANAS (2016) Plano Estratégico Nacional de Gestão e Prevenção de Resíduos Sólidos em Cabo Verde. PENGER.

https://portondinosilhas.gov.cv/portonprd/porton.POR_DET_AREA_DB.open_file?p_doc_ $\underline{\mathrm{id}=165}$

[10] Inocêncio, D. (2012) Construção e Arquitetura Sustentáveis em Cabo Verde-Estudo de Estratégias de Projeto Sustentável. Dissertação, Universidade Técnica de Lisboa.

[11] Semedo, J. (2009) Tecnologias de construção em Cabo Verde-Uso de recursos naturais e impactes ambientais, Jornadas Técnicas da $1^{\text {a }}$ Feira Internacional da Construção e Habitação. Partilhar, Inovar e Experimentar, UniCV, Praia.

[12] Fortes, M.S.A (2014) Influência da Mão-de-obra na Qualidade da Construção Civil Importância da Capacitação da Mão-de-obra na Construção Civil em Cabo Verde

[13] Lopes, A.A. (2013) Construção Sustentável: Medidas Construtivas Sustentáveis que Buscam Aumentar a Eficiência no Uso dos Recursos e Minimizar os Impactos ao Meio Ambiente. (Dissertação)—Escola Politécnica, Universidade Federal do Rio de Janeiro, Rio de Janeiro, $124 \mathrm{p}$.

[14] Torgal, F.P. and Labrincha, J.A. (2013) The Future of Construction Materials Research and the Seventh UN Millennium Development Goal: A Few Insights. Construction and Building Materials, 40, 729-737. https://doi.org/10.1016/j.conbuildmat.2012.11.007

[15] Jeffrey, C. (2011) Construction and Demolition Waste Recycling-A Literature Review. Dalhousie University's Office of Sustainability, Halifax. 
Submit or recommend next manuscript to SCIRP and we will provide best service for you:

Accepting pre-submission inquiries through Email, Facebook, LinkedIn, Twitter, etc. A wide selection of journals (inclusive of 9 subjects, more than 200 journals)

Providing 24-hour high-quality service

User-friendly online submission system

Fair and swift peer-review system

Efficient typesetting and proofreading procedure

Display of the result of downloads and visits, as well as the number of cited articles

Maximum dissemination of your research work

Submit your manuscript at: http://papersubmission.scirp.org/

Or contact jep@scirp.org 